\title{
Impact of Rapid Urbanization and Changing Housing Patterns on Urban Open Public Spaces of Amman, Jordan: A GIS and RS Perspective
}

\author{
Yahya Farhan1, Sireen Al-Shawamreh ${ }^{2}$ \\ ${ }^{1}$ The Trustee Council of Al-Ahliya University, Amman, Jordan \\ ${ }^{2}$ Department of Geography, University of Jordan, Amman, Jordan \\ Email: farhan@ju.ed.jo, syr9120360@fgs.ju.edu.jo
}

How to cite this paper: Farhan, Y. and Al-Shawamreh, S. (2019) Impact of Rapid Urbanization and Changing Housing Patterns on Urban Open Public Spaces of Amman, Jordan: A GIS and RS Perspective. Journal of Environmental Protection, 10, 57-79.

https://doi.org/10.4236/jep.2019.101005

Received: December 3, 2018

Accepted: January 15, 2019

Published: January 18, 2019

Copyright $\odot 2019$ by author(s) and Scientific Research Publishing Inc. This work is licensed under the Creative Commons Attribution International License (CC BY 4.0).

http://creativecommons.org/licenses/by/4.0/

\begin{abstract}
Rapid urbanization and population growth of the Amman Area were combined with land resource degradation when the city was heading for mounting urbanization from the early 1950s. The deterioration of natural resources and green areas, was coupled with the creation of different urban public open spaces in the city. The transformation from large single-family houses to dense residential apartments was associated with social and behavioral changes among the inhabitants living in the dense apartments. Consequently, a large private sector has been developed to provide public and social spaces. Photo-interpretation and satellite images were used to map and characterize land use/cover changes have been occurred in the Amman area between 1953 and 2017. Maximum Likelihood Classification method was employed to identify land use/cover changes between 1986 and 20017, and GIS was utilized also to map examples of the recently emerged socio-economic open spaces. Excessive urban development in the last two decades, and the adoption of neo-liberal privatization policies by the government, enhanced social stratification and residential segregation. So, instead of encouraging outdoor activity and social interaction among all groups of Amman residents, the freedom of accessibility to major open spaces has been restricted within the same urban fabric, thus, the "two Ammans" paradigm, a "tale of two cities", has been recently acknowledged.
\end{abstract}

\section{Keywords}

Urban Public Space, Private Space, Landsat Images, Air Photos, Land Use/Cover, Amman

\section{Introduction}

The urban public and social spaces are becoming a central concern for urban 
planners, architects, geographers, economists, politicians, and sociologists [1]. This complex is considered a vital part of cities, where it encourages outdoor activity and social interaction, serving to enhance the quality of life and health of urban residents, a key factor in establishing and maintaining sustainable cities. Other researcher notes that public space is "our open-air living room, and our outdoor leisure center" [2].

Public spaces are the appropriate places to maintain a public presence, and to promote tolerance and diversity. They facilitate idea exchange, friendship, goods, services and skills. Public space can also play a vital role in everyday social life of communities [3]. Such spaces are important for well-being and health of residents of all age groups. Public space is defined as "being accessible" to all groups, providing "freedom" of action, temporary claim and "ownership" [4]. It is recognized that exposure to "eco-natural" encompassing landscape, and practicing outdoor physical activities in free time, at home and work, are substantial factors for urban well-being; and the sustainability of urban areas [5]. Daily contact with nature, or any type of interaction with nature for persons of all ages, in particular children and youth, is recommended to achieve a healthy community. Hence, it is important to elaborate on how an urban population experiences different types of nature in their daily life [6]. Rasidi et al. [7] evaluated the green space design of typical green spaces that are believed to enhance social interactions among new township residents in Malaysia. They analyzed the design quality of green spaces that could promote social interaction, and the activities that could unite people, and had potential to reduce negative social behavior, i.e. aggression and violence in the city. They suggest that diversity of sub-spaces including vegetation density, animal population, undulating morphology, urban green spaces, and park areas, water bodies, and concrete provisions for social interaction are generally favorable places for encouraging social interaction.

It has been argued elsewhere [8] that most people like to visit green spaces regularly to enjoy meeting and, interacting with other groups of people, and establishing new friendships that might lead to the feelings of attachment to the place and stronger community cohesion. Lau [9] stressed that urban parks can enhance the quality of life, a key factor in building a sustainable city. Thus, it is impossible at present to implement urban development projects without creating different types of public spaces (i.e. squares and parks) as a common platform to exchange goods, experience, knowledge, culture and amenities [10].

Carmona et al. [11] discuss at length the notion of "public places and public spaces", in relation to urban design dimensions. They note that the physical public domain refers to a series of spaces and settings that facilitate public life and social interaction. It represents sites or settings of formal and informal public life that have "physical" (i.e. spatial) and "social" (i.e. activity-oriented) dimensions. The results of activities and events carried out within urban spaces can make it a "socio-cultural" domain. A research project on the use of three types of public space in Alesbury (northwest of London, England) has explored 
residential neighborhoods, green open spaces, and town center spaces, including central squares and shopping areas [12]. The researchers examined how different people use public spaces and assessed how social interactions vary by age, gender and, place, and the "use of other spaces", i.e. their own homes and other indoor facilities. The results were analyzed with reference to their relevance for emerging policy agendas regarding shared and contested spaces, intergenerational relationships, safety and security, and the management of public space. Finally, Holland and her colleagues suggest that the most important element for "designing in inclusion" in new public space are to: 1) include all age groups and social groups in ideas for the design, drawing on public consultation and involvement; 2) encourage a strong sense of local "distinctiveness", and; 3) look at evolving a range of spaces with different security regimes, including "light touch" regulation.

In East Asia, Chen et al. [13] examined the relationship between utilization and quality of community as manifested in open spaces in China, with reference to the overseas Chinese town community in Shenzhen. The connection between the number of visitors and space characteristics has been also evaluated using multivariate regression models. Results reveal that large areas with accessible lawns, well-maintained footpaths, commercial facilities, benches, and bodies of water are vital components that encourage physical activities and increase the use of community open spaces, thus, intensifying the outdoor activities of residents.

In the recent past, research has been focused on analyzing the accessibility of urban open spaces, where accessibility is considered the most essential factor influencing their use [14] [15]. Others however, stated that a distance of $300 \mathrm{~m}$ to $400 \mathrm{~m}$ from a user to an open space is considered an important "distance threshold" [16]. When the distance is greater than $400 \mathrm{~m}$, the use frequency decreases substantially. By contrast, Giles-Corti et al. [17] revealed in a study on Perth (Australia) that among open spaces with similar scales, $70 \%$ of the respondents favor visiting open spaces that they find most attractive rather than nearest ones.

Furthermore, Lau [9] investigated the design and functions of small public urban open spaces (SPUOS) in Hong Kong, in order to identify the motivation of visitors for using them. The design of the SPUOS was assessed with the help of public design guidelines issued by the government. It is reported that benches are the only facility installed and a small amount of vegetation has been created. They argue that the size of a park is not the major concern of park users surveyed, but rather associated facilities and the design style. Further, they conclude that a network of connected SPUOS might serve the local community more efficiently due to their location. However, since few amenities are provided, SPUOS could not entirely replace large urban parks.

Thompson [18] explores what should be demanded from urban open space in the 21st century, including the spatial and social implications of a particular socio-economic mode of life, changing values, and attitudes towards nature and sustainability. Then a model for future urban life, and the associated urban open 
space that might accommodate these changes were suggested. It has been concluded that urban open space must provide an appropriate places where all groups can meet and interact socially, expeience cultural diversity, engage with natural landscapes, conserve public and private memories, and to serve a central function in defining "the identity of various societies". A semi-radical approach was employed to examine the urban public space of Amman [19]. The concept of "space" was addressed with reference to three widely-recognized structural theories: 1) the production of space as discussed by Lefebvre [20];2) the life space and economic space analyzed by Fridemann [21]; and 3) the structural transformation of space elaborated by Habermas [22]. The exploited public spaces of Amman, and the newly produced spaces by the power of privatization controlling and shaping the municipalities and their policies were discussed.

The potential threat of public space by certain practices in the last two decades was also analyzed based on evaluating the factors producing public space, factors influencing the practices with in public space. Khawaja [19] also argued that the neo-liberalism approach adopted by the government in the last two decades, and the pursuit of neo-liberal policies, have produced new private spaces which now often predominate over traditional public spaces. The gated communities coupled with privatized urban public space, and (even) the newly emerged wall-gated large houses associated with "private" open space (i.e. gardens with an area > $200 \mathrm{~m}^{2}$, and swimming pools) are iconic examples. The increase of population density in eastern Amman has created a crucial threat to present open public spaces, and act to reduce the potential of future availability of open public spaces, streets, pavements, and market areas, sidewalks and parks. In light of the radical transformation pushing towards economic liberalization, and the associated urban development patterns, including public space production, the government failed to achieve social chesion and equity within the urban population. Instead, the gap between the emergent housing projects/communities in western and eastern Amman has been progressively widened, thus, gradually but steadily increasing social disparities between the rich and poor socio-economic strata. Consequently, social cohesion in the city is expected to decline to a critical degree [23]. However, Tawil et al. [24] argue that urban transformation taking place recently in Amman, reinforces the need for substantial change in public space, in order to make public spaces more publicly accessible, open, and uncontrolled. The demand for public space with reference to socio-economic life, and the role of open space must be analyzed and described based on the actual documented perceptions of local residents of Amman.

The objectives of the current research are:

1) to gather empirical data on the rapid urban growth and the LULC change dynamics in the Amman Metropolitan Area, using Geographic Information System (GIS) and remote sensing (RS) techniques;

2) to assess the impact of rapid urbanization of Amman on changing housing patterns, the behavior of residents, and the need for urban social spaces; 
3) to recognize the developed urban open spaces, including traditional and privatized modern spaces;

4) to analyze the impact of neo-liberalism and privatization on development of private urban spaces; such as closed gated communities, which have produced social segregation and disintegration.

\section{Study Area}

Amman City is the capital of Jordan. It is located at $31^{\circ} 24^{\prime \prime} \mathrm{N}$ to $32^{\circ} 2^{\prime \prime} \mathrm{N}$ latitude and from $35^{\circ} 35^{\circ} 67^{\prime \prime E}$ to $36^{\circ} 43^{\prime \prime E ~ l o n g i t u d e ~(G o v e r n o r a t e ~ o f ~ A m m a n), ~ a n d ~ o c c u-~}$ pies the center of the historical rainfed ecumene characterizing the central and northern highlands, east of the Rift (Figure 1). This region is dissected by incised intermittent wadis which have resulted in a hilly landscape (each hill is locally termed "jebel") and deep valleys coupled with steep valley-side slopes. The morphology of the rounded and flat-topped hills results from fluvial erosion that occurred in the Amman formation, which consists of limestone interbedded with chert, marl and chalk beds [25]. Folded strata (anticlines and synclines), faulting and jointing are observed in the Amman metropolitan area [26], which compromise a part of the Amman-Hallabat structure [27].

Notable tectonic and seismic activity have increased since the mid-1970s [28] [29]. The tremors of 1992, and the many earthquakes of 1995-1996 substantiated this trend [30] [31]. The old city center is located at the base of seven jebles (Figure 2), and since the 1950s the built-up area has expanded rapidly over the nearbyjebels, across the rangeland and cultivated lands on the valley side slopes, and top of jebels to the south, west and north. Currently, the city is distributed over 19 hills, and the Greater Amman Municipality covers an area of $801 \mathrm{~km}^{2}$ [32]. The old city center is located at an elevation of $750 \mathrm{~m}$ (a.s.l) approximately. Over the last thirty years, the city has expanded to occupy higher lands at elevation reaching $980 \mathrm{~m}$ (the Jubeiha neighborhood). The Wadi or "Seil" Amman, which meanders through the city, flows east and north to the Zarqa river. The source of Seil Amman flows from storm runoff and Ras el Ain springs. Interpretation of air photos of $1953(1: 25,000)$ and $1961(1: 100,000)$ shows that the flood plain of the Amman stream (200 - $400 \mathrm{~m}$ of width) from Ras el Ain (through Rusiefa and Zarqa cities) to the Sukhna town (about $30 \mathrm{~km}$ in length), was utilized intensively for irrigated agriculture and fruit trees (Figure 2 \& Figure 3). The climate of the western part of Amman is sub-humid Mediterranean, whereas the northern and southern parts are semi-arid. Generally, the city experiences cold winters and hot summers. The average daily mean temperature in January is about $2^{\circ} \mathrm{C}-8^{\circ} \mathrm{C}$, and in August averages $26^{\circ} \mathrm{C}$. The average annual rainfall ranges from $290 \mathrm{~mm}$ at jebel $\mathrm{Al}$ Hussein to $473 \mathrm{~mm}$ at Jubeiha [33].

\section{Materials and Methods}

Recent advances in remote sensing (RS) and geographic information system (GIS) technology enable effective modeling of urban growth. Through remote 


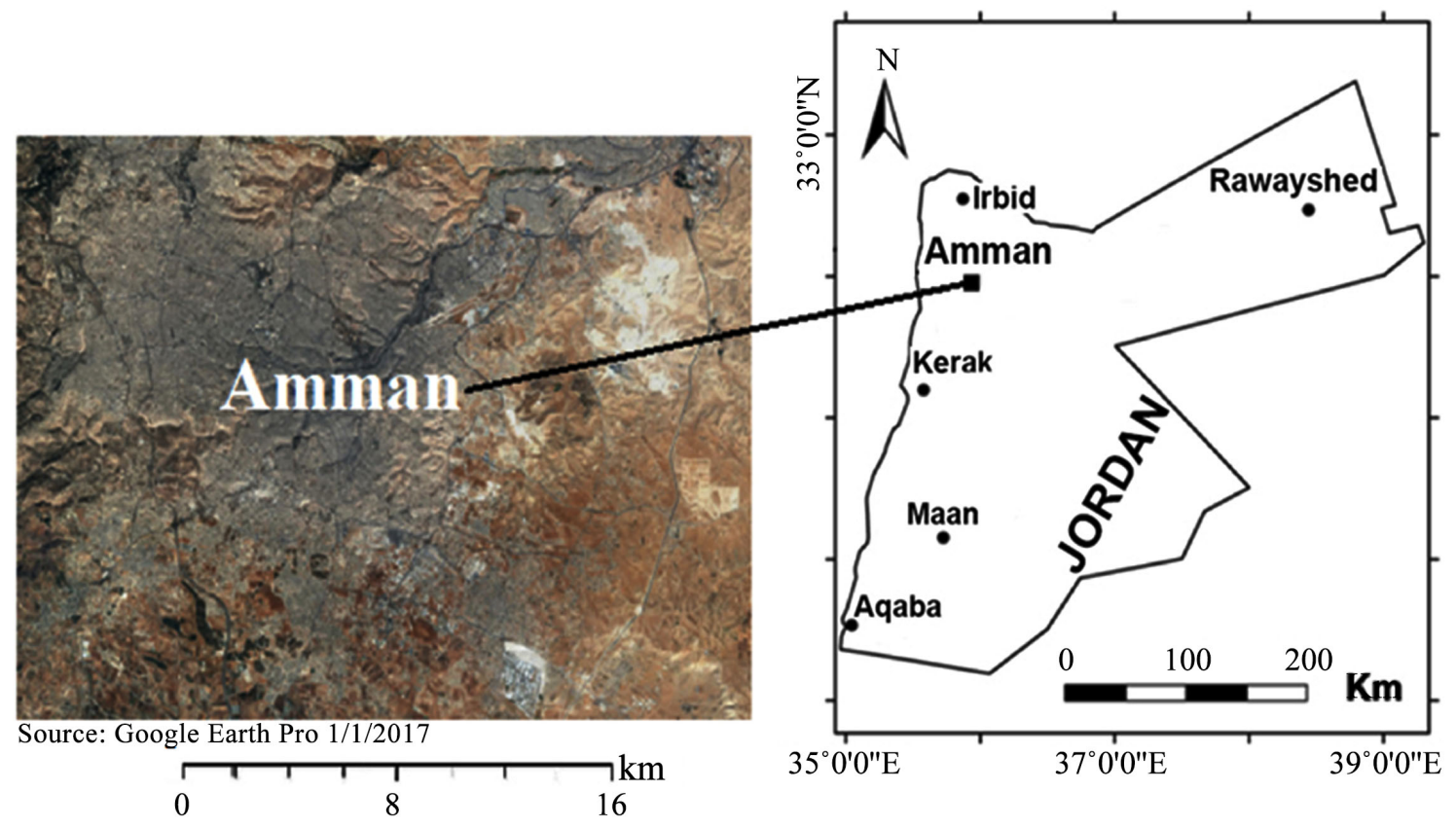

Figure 1. Location of the study area.

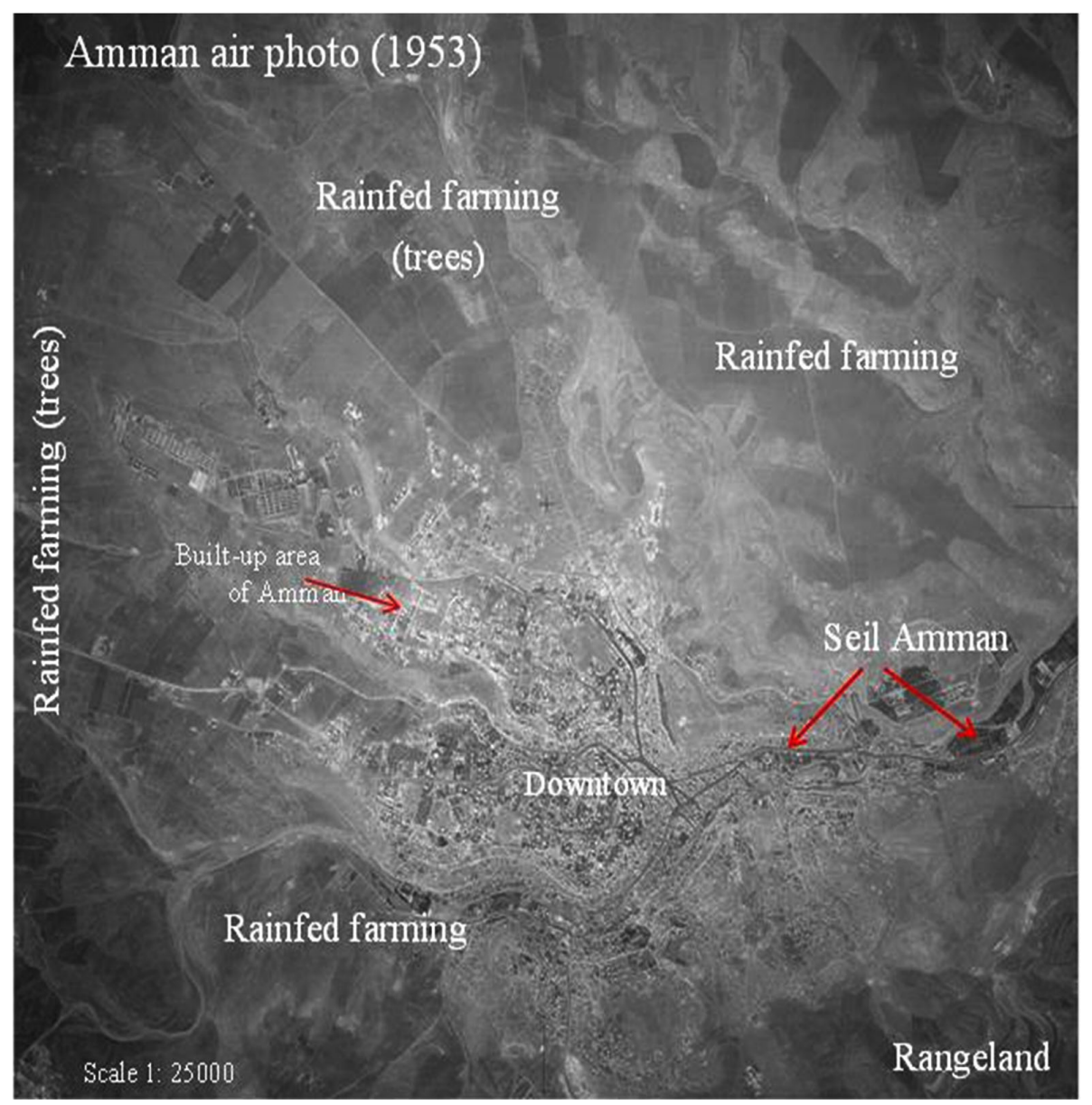

Figure 2. Air-photo of Amman (1953) shows the Seil, irrigated agriculture, the down town, overlapping of the built-up area with the rainfed farming and rangeland. 


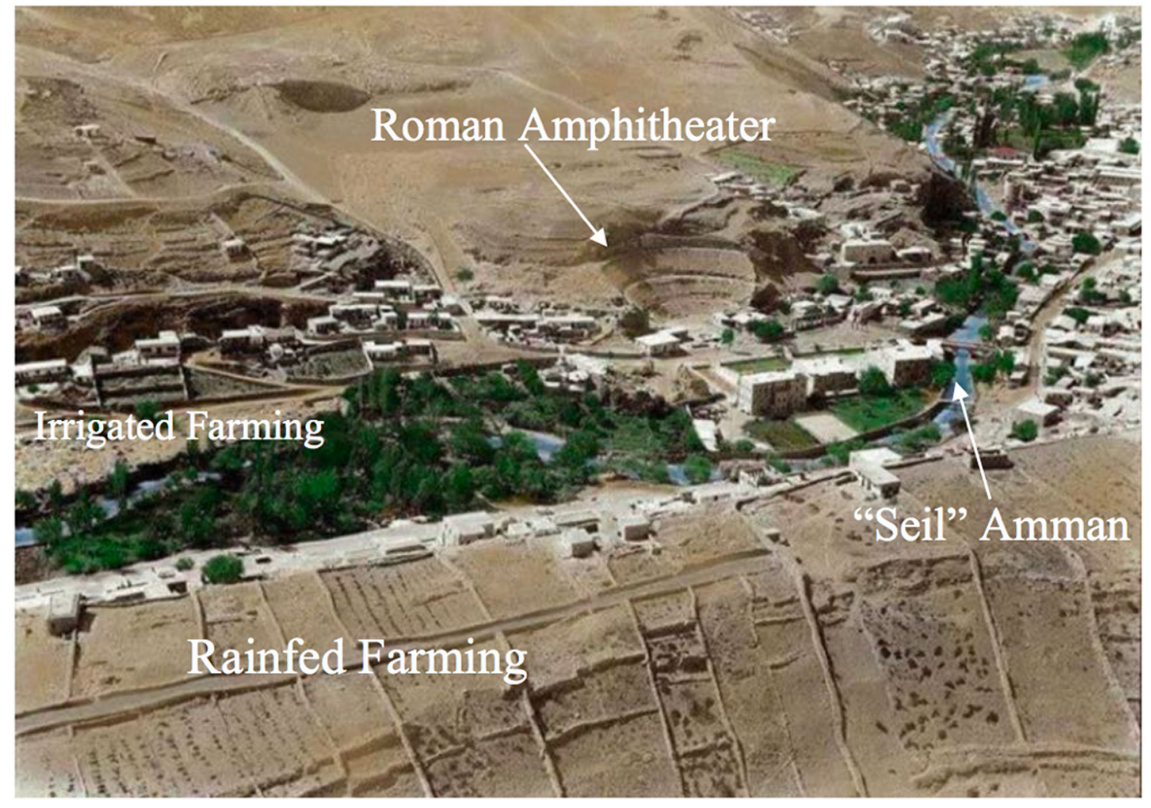

Figure 3. Irrigated farming along the Seil of Amman (1920), north and south of the Roman Amphitheater.

sensing and satellite images, it is possible to extract accurately and timely geospatial information on land use/land cover changes in the metropolitan area of cities. Extensive urbanization has caused chaotic growth in Amman, decline in environmental quality, living conditions and human health as a result of radical man-made changes in the urban landscape. Historical analysis of LULC dynamics, and expansion of the built-up area of metropolitan Amman was carried out using successive air photos (1953, 1961, 1978, and 1981) and satellite images (1986, 2003, and 2017). Change detection for LUCU was undertaken to describe and quantify the pattern of LULC changes and differences between images of the Amman Metropolitan Area at different times, and the implication of LULC change dynamics on environmental degradation of the city (Figure 4). The generated maps based on photo-interpretation, digital image processing (supervised classification) and GIS software, show that the population and the built-up area of Amman have increased dramatically between 1953 and 2017. Other categories of LULC classes have progressively decreased during the same period over the entire area. Land use/cover dynamics and the expansion of the build-up area of Amman; was analyzed using air photo coverage purchased from the Royal Jordanian National Geographic centre (RJNGC), Amman. Visual interpretation of air photos was conducted using a Topcon Mirror stereoscope. Thus, five categories of LULC were recognized, with a limited field observation/check. Air photo data were obtained at different dates and scales, and were rectified geometrically using the Google Earth Pro 2017, 200 ground control points, and the Transverse Mercator Coordinate System. LANDSAT imagery was downloaded from the earth explore site of the USGS. The detail of satellite data/image specifications, and air photos are illustrated in Table 1. Using ENVI (5.4), LANDSAT 5-TM, 1986; LANDSAT 7-TM 2003; and ESA's Sentinel 2 Mission 2017 images (Table 
1(a) and Table 1(b)) were analyzed using the supervised classification technique. The Maximum Likelihood Method was employed to classify LULC categories [34]. Arc GIS (10.5) software was employed to: 1) map examples of urban and social spaces; 2) visualize the processed images and 3) generate LULC conditions maps illustrating the three successive periods of study [35]. The images were geometrically corrected, and four bands (blue, green, red, and NIR) were selected for Landsat and ESA's Sentinel 2 Mission image processing so as to detect changes in LULC. All data utilized in this investigation were projected into the Universal Transverse Mercator (UTM) projection system with WGS 84 reference system. The LULC classes identified are: built-up area, rainfed farming, irrigated agriculture, rangeland, and bare land (Table 2). Further, secondary information on the Amman area was collected from published, and unpublished surveys, direct observation/field survey, and informal interviews with experts from the Greater Amman Municipality (i.e. planners and engineers). The prominent deterioration of LULC, and the expansion of the built-up area of Amman are illustred in maps compiled by Arc GIS. The land use/cover statistics were also calculated and are summarized in a special table, in order to detect changes that occurred between 1986 and 2017 in the Amman Metropolitan Area.

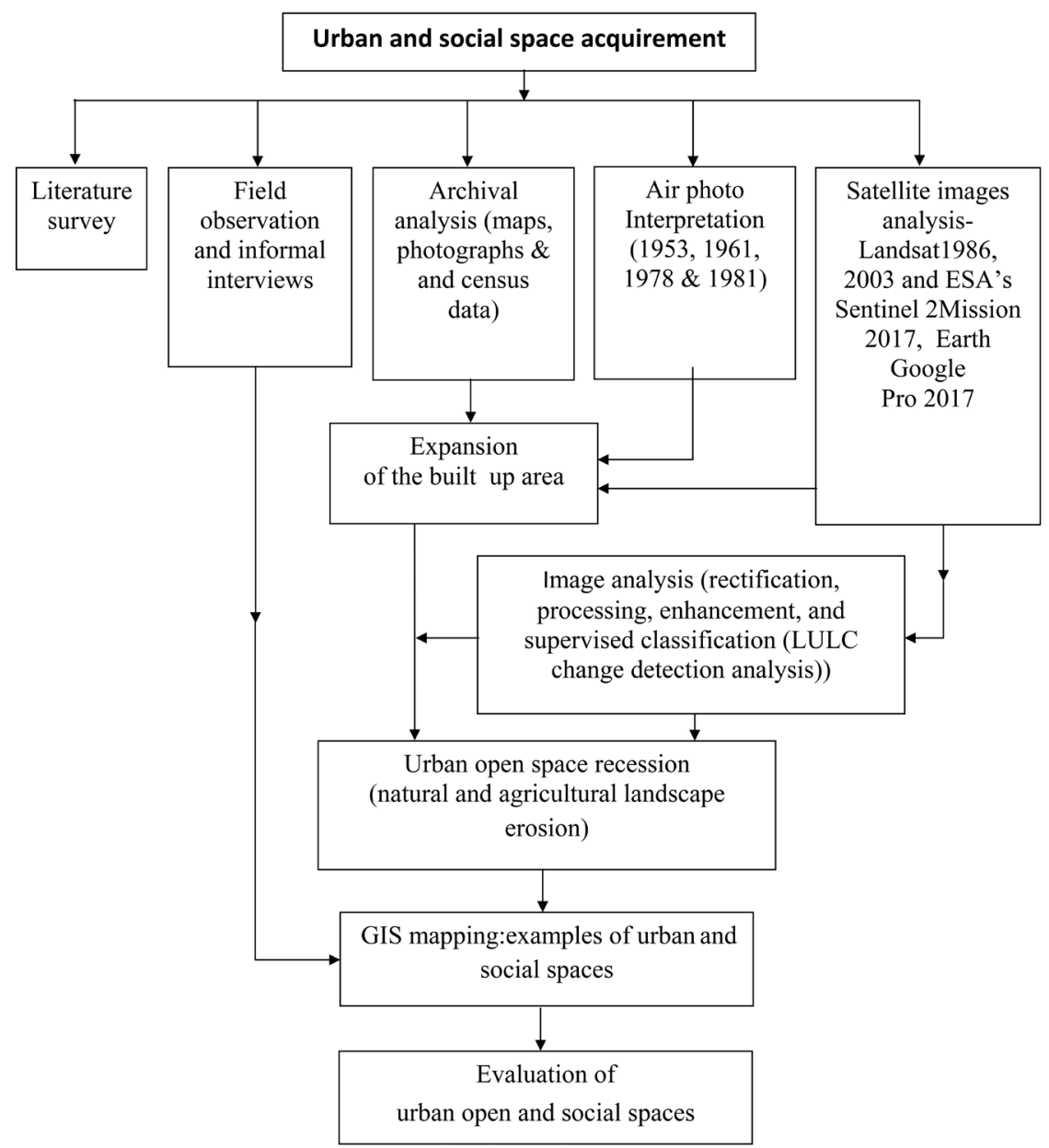

Figure 4. Methodology. 
Table 1. (a) Satellite images specifications out. (b) Air photos specifications, and Google Earth Pro 2017.

(a)

\begin{tabular}{|c|c|c|c|c|}
\hline \multirow{6}{*}{$\begin{array}{l}\text { Satellite } \\
\text { images }\end{array}$} & Image & $\begin{array}{l}\text { Resolution } \\
\text { (m) }\end{array}$ & $\begin{array}{c}\text { Image } \\
\text { specifications }\end{array}$ & Source \\
\hline & 1) ESA's Sentinel 2 & $20 \times 20$ & Blue band & The European Space \\
\hline & Mission (2017) & & $(0.45-0.52)$ & Agency's Sentinel 2 Satellite \\
\hline & & & $\begin{array}{l}\text { Green band } \\
(0.52-0.60)\end{array}$ & \\
\hline & 2) Landsat 5-TM (1986) & $30 \times 30$ & $\begin{array}{l}\text { Red band } \\
(0.63-0.69)\end{array}$ & $\begin{array}{l}\text { From the Earth Explore Site } \\
\text { of the USGS }\end{array}$ \\
\hline & 3) Landsat 7 TM (2003) & $30 \times 30$ & $\begin{array}{l}\text { NIR band } \\
(0.76-0.90)\end{array}$ & \\
\hline
\end{tabular}

(b)

Google Earth Pro 2017

\begin{tabular}{|c|c|c|}
\hline \multicolumn{3}{|c|}{ Google Earth Pro 2017} \\
\hline \multirow{5}{*}{ Air photos } & 1) Scale $1: 25,000$ (1953) & \multirow{5}{*}{ (RJNGC) } \\
\hline & 2) Scale 1: 100,000 (1961) & \\
\hline & 3) Scale $1: 10,000$ (1978) & \\
\hline & (scattered photos) & \\
\hline & 4) Scale $1: 60,000$ (1981) & \\
\hline
\end{tabular}

Table 2. Details of land use/cover classes.

\begin{tabular}{|c|c|}
\hline LULC types & Description \\
\hline Built-up area & $\begin{array}{l}\text { This class represents the built-environment, all man-made } \\
\text { infrastructures, i.e. buildings, roads network, and concretized areas }\end{array}$ \\
\hline Rainfed farming & Cultivation based on rainfall \\
\hline Irrigated agriculture & Irrigate agriculture based on man-made springs, wells and ponds \\
\hline Rangeland & $\begin{array}{l}\text { Seasonal grazing areas. This land belongs to the state, and located } \\
\text { outside municipal boundaries, including the tribal lands }\end{array}$ \\
\hline Bare land & Land not suitable for grazing, mostly without any soil cover \\
\hline
\end{tabular}

\section{Results and Discussions}

\subsection{Population Growth and Urban Development of the Amman Metropolitan Area}

Population growth and rapid urbanization has become a major factor in environmental degradation of cities. Excessive urban and sub-urban development dramatically affects land use/land cover, biodiversity, habitat structure, loss of species, and hydrosystem changes in the urban region [36] [37]. Over the course of the $20^{\text {th }}$ century, and the first decade of the $21^{\text {st }}$ century, the population of Amman has increased rapidly from nearly an abandoned archaeological site to a modern city since late 1980s which accommodates several millions inhabitants [38]. The total population of the town in 1907 consisted of only 300 families [34], and in 1918, the population was estimated at less than 5000 inhabitants, 
while the built-up area of the city approached $0.321 \mathrm{~km}^{2}$ [35]. In 1921, Amman was declared the capital of a newly established state named "Trans Jordan". Population growth and urban development of the city continued in parallel with the emerging economic prosperity [34]. It occupies the locality of the present old downtown area north and east of the Roman Amphitheater [39]. From 1921 to the early 1950s, the city witnessed slow urban growth; where the population was estimated at 10,500 in 1930, and 45,000 in the early 1940s. The built-up area covered only $2.5 \mathrm{~km}^{2}$ by 1947 [40]. The population of Amman in 1945 was estimated at 60,000 inhabitants. In 1950, Amman City was transformed into a Municipality, and in 1952, the city was declared the capital of the Hashemite Kingdom of Jordan (East and West Banks of Jordan). The first circle of Jebel Amman appeared in 1940, followed by the second circle in 1950, and no building existed at that time in the area [23]. Following the first Palestinian refugee wave in 1948 (who were expelled by the Israelis from their homeland after the establishment of the state of Israel), the total population of Amman in 1952 rose abruptly to 250,000 inhabitants, and the estimated built-up area was at $4.123 \mathrm{~km}^{2}$ (based on air photos of scale 1:25,000, taken in 1953), while the total population of Jordan in 1952 was estimated at 586,002 [41]. Again, the total population of city increased sharply from 350,000 in 1967, to reach 520,000 of inhabitantsin 1971 following the 1967 Arab-Israeli War [42] [43] [44]. In 1974, the total population of the city had increased to nearly 600,000 , and in 1979, the total population reached 777,800. The built-up area of the city was estimated at $101 \mathrm{~km}^{2}$ [45], and in 1983 , the built-up area reached $105.675 \mathrm{~km}^{2}$ [38]. Similarly, the total population of Amman was estimate at 1,013,000 inhabitants in 1987, whereas in 1994, following the Gulf War, the total population was 1.4 million, and the built-up area was estimated at $150.8 \mathrm{~km}^{2}$. Urbanization of Amman continued its upward spiral, and total population reached 1,726,713 million in 2002 [46], living over a build up area estimated between 155 and $163 \mathrm{~km}^{2}$. Likewise, the total population of Amman in 2007 and 2013 amounted to 2.17 millions, and 2.5 millions respectively, and the built-up area increased to reach $280 \mathrm{~km}^{2}$ in 2017 . The total population of Amman was estimated at 4,007,500 inhabitants in 2015, a huge increase from 2013 due to Iraqis and Syrian influx, and the total population of Jordan at that juncture was $9,798,000$ [47]. Remarkably, since the beginning of $20^{\text {th }}$ century, the population of Amman has doubled more than 500 times, and Abu Ayyash [48] has stressed "that no city in the world has grown at the same rate of growth as of Amman". "It is rightfully an immigrant city". The successive flows of refugees and migrants are essentially unplanned and thus, uncontrolled urbanization results in the deterioration of land resources, i.e. natural and green areas, agricultural land, rangeland, and water resources. For that reason, the city has been described recently by Khawaja [19] as "an ever-growing city worldwide", with a high population growth rate ranging from 10.5\% (1952-1961) to $4.5 \%$ (1980-1990); coupled with a high diversity of population. The migration impact on the population growth rate varies from $7.2 \%$ (1952-1961), to $1.0 \%$ 
(1980-1990). Other factors which caused a sharp increase of population of Amman during the period 1950-2015 are: 1) excessive population growth, particularly following the 1948 and 1967 wars, and the occupation of Palestine and the the West Bank of Jordan; 2) the 1991 Gulf War and the return of 0.5 million Jordanian labor from the Gulf States, and the settlement of 0.5 million Iraqi refugees in the country following the 2003 war on Iraq; and 3) the influx of Syrian refugees ( 0.5 million approximately) who fled to Jordan following the outbreak in 2011 of the war in Syria [43] [49] [50]. The continuous increase in the built-up area of Amman, was associated with a progressive decline in rainfed cultivation, irrigated farming, and rangeland (Figure 5 \& Figure 6). The difference between the buil-up area of Amman in $1952\left(4.123 \mathrm{~km}^{2}\right)$ and in $2017\left(280 \mathrm{~km}^{2}\right)$ reveals that large rainfed farming areas, rangeland, and the natural landscape have been continuously decreased, whereas, bare land has been successively increased. The irrigated agricultural and dry farming and infilled wadis, were transformed to major highways across the wadi floors. Similarly, the rainfed farming and range land areas were utilized particularly for residential development. Unfortunately, even the lands with soils classified as class (A) of capability has been transformed to refugee camps (i.e. the Baqa'arefugee camp), $14 \mathrm{~km}$ west of Amman down town [51]. Accordingly, the rate of increase in built-up area was extremely high, and the decrease in agricultural lands and rangeland was dramatic over the time period between 1952 and 2017. High growth rates caused serious urban crises such as in connection with traffic, transport, water, waste disposal, and housing.

\subsection{Land Use/Cover Changes Dynamics: Environmental Degradation of the Amman Metropolitan Area}

Recent advances in remote sensing (RS), and geographic information systems (GIS) techniques enable researchers to model urban growth effectively, and to extract, analyze, and simulate land use/cover efficiently.

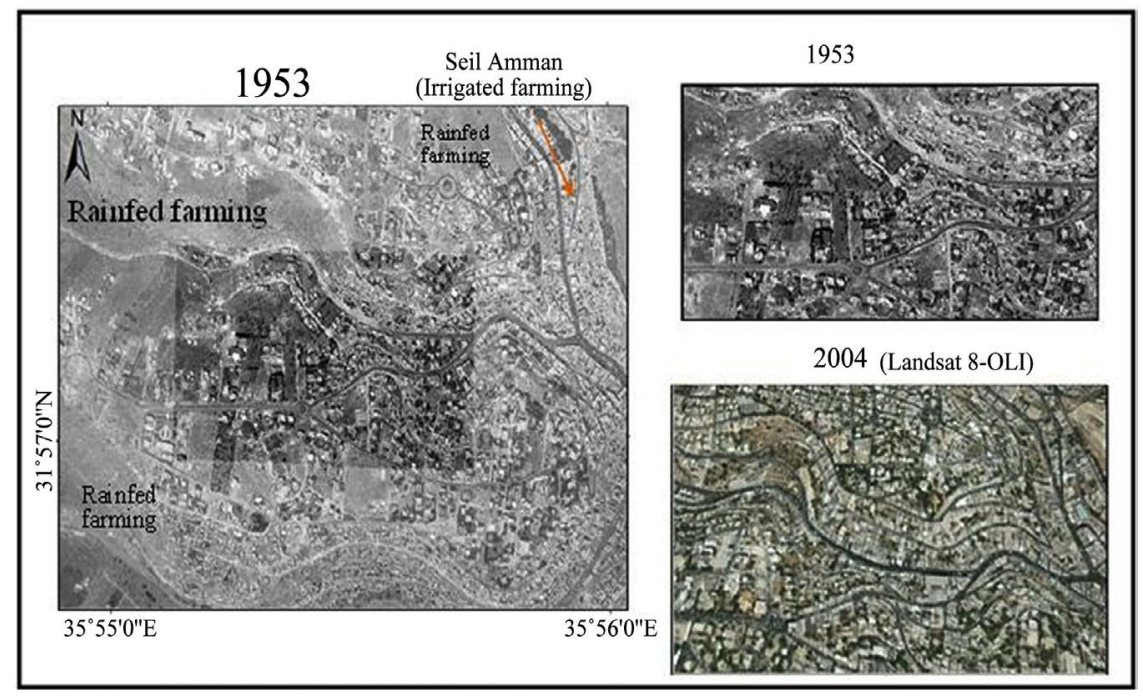

Figure 5. The built-up area in 1953 compared with the dense buildings in 2004 . 


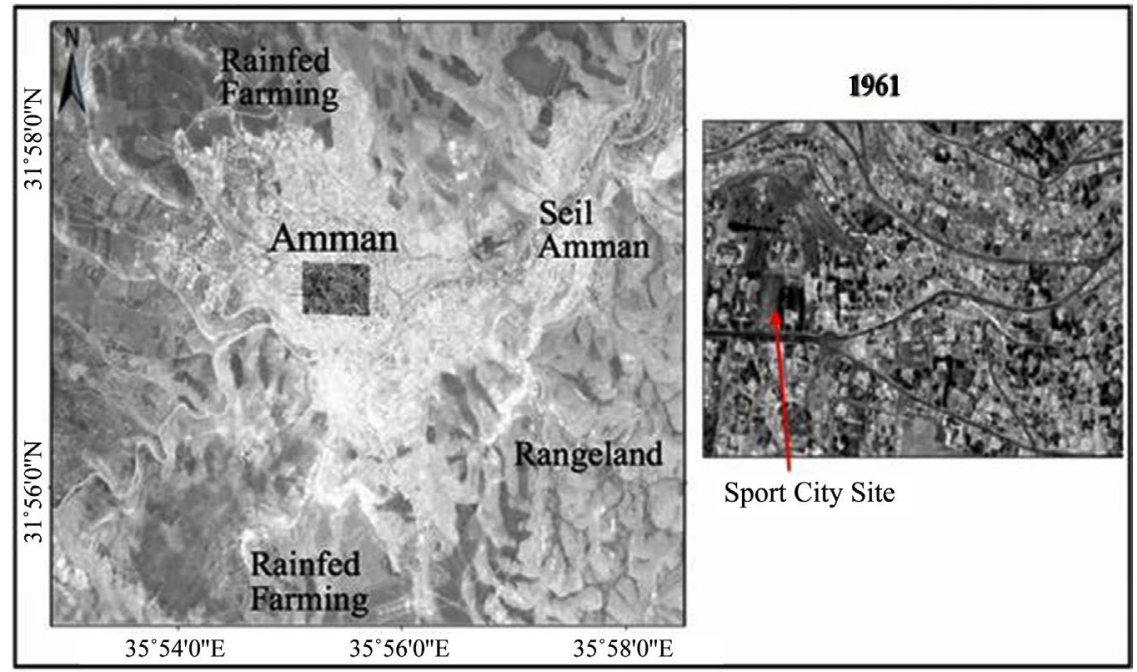

Figure 6. The expansion of the built-up area in 1961. It shows the site of Al-Hussein sport city, where it was fertile rainfed farming.

Remote sensing (RS) and GIS tools also can be employed to illustrate land use/cover changes in metropolitan areas [52]. Visual interpretation of historical and current aerial photographs (1953-1981) and satellite images (1986-2017), indicate that until the 1960s, the main land use/cover classes in the Amman Metropolitan Area comprised the following: urban, rainfed cultivation (cereals, fruits and olive trees, summer vegetables), irrigated farming (mainly vegetables and fruit trees), small patches of forests, rangeland, and bare land (soil and rock). The residential and agricultural areas overlapped in the city of Amman, with consistent invasion of urban development onto fertile rainfed farming land, and particularly the impact of residential expansion, with continuous encroachment upon adjoining rural settlements [53]. Thus, a prominent degradation of land resources in and around the Amman Metropolitan Area has been occurred (Figure 7). The expansion of the built-up area is presented in Figures 8(a)-(c), and Figure 9. The land use/cover statistics were calculated and illustrated in Table 3 to detect changes that occurred between 1986 and 2017. There was a dramatic increase in the percentage of built up area from 1986 to 2017 (Table 3). Moreover, rainfed farming area and rangeland significantly decreased in the same period of time. Rainfed land and rangeland have been continuously invaded by residential development in the north, west, and southern parts of the city. The rate of increase in the built up area has been very high in the past twenty years. In 1986, the constructed area was $169 \mathrm{~km}^{2}$, whereas in 2017, it is computed at $280 \mathrm{~km}^{2}$ (47\% of the total area, Table 3 and Figure 9). All the land use/cover categories have been changed involving both gains and losses: gains (i.e. the built up area and bare land), losses, (irrigated agriculture, rangeland, and rainfed farming) during the same period of time (Table 3). Moreover, the built up area increased by $280 \mathrm{~km}^{2}$, while the rainfed farming and rangeland decreased by $69 \mathrm{~km}^{2}$ and $133 \mathrm{~km}^{2}$ respectively (Table 3). The output of GIS map classification for the three periods: 1986, 2003, and 2017 (Figures 8(a)-(c)) 
clearly illustrates the increment and decrement in the land use/cover in any particular space in the Amman Metropolitan Area. Consequently, the city is considered "environmentally degraded", where the "countryside has been extremely eroded". In contrast, the city can be simply described as "an exceptional agglomerate of rural and tribal traditions, highly western sophistication, modern urban crisis, and refugee problems". Although, community gardens and parks were not available during the 1950s; rainfed and irrigated farming areas, wildlife, and a small number of traditional cafes close to the "Seil", were considered to be an open space. The local communities of Amman have experience indirect types of interaction with nature through a range of customary practices, leisure time, and social activities. In 1966, the first public space, Al-Husein Sports City was

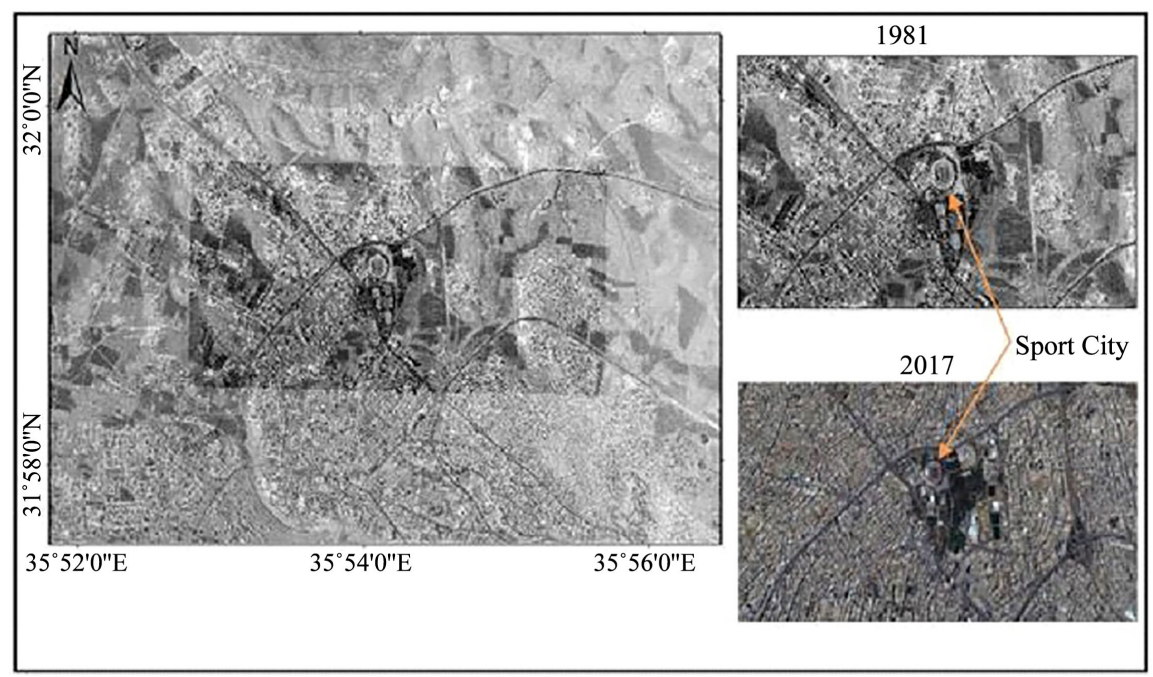

Figure 7. Amman in 1981 and Al Al-Hussein sport city (1966), and the same area asappeared in Google Earth Pro 2017.

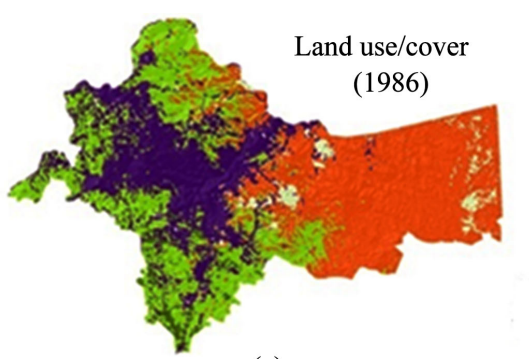

(a)

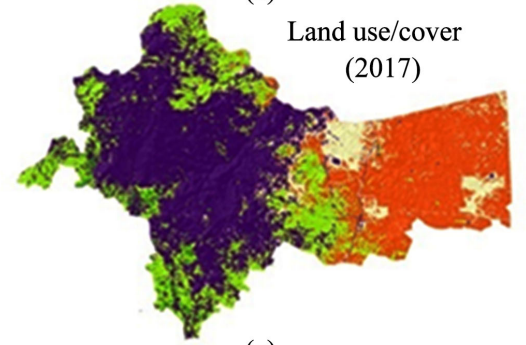

(c)

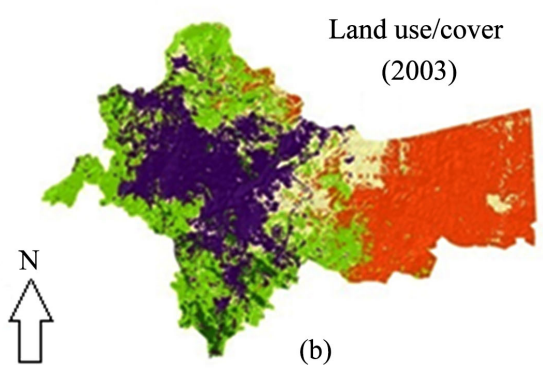

(b)

Figure 8. Land use/cover maps of Amman Metropolitan Area in 1986 (a), 2003 (b), and 2017 (c). 


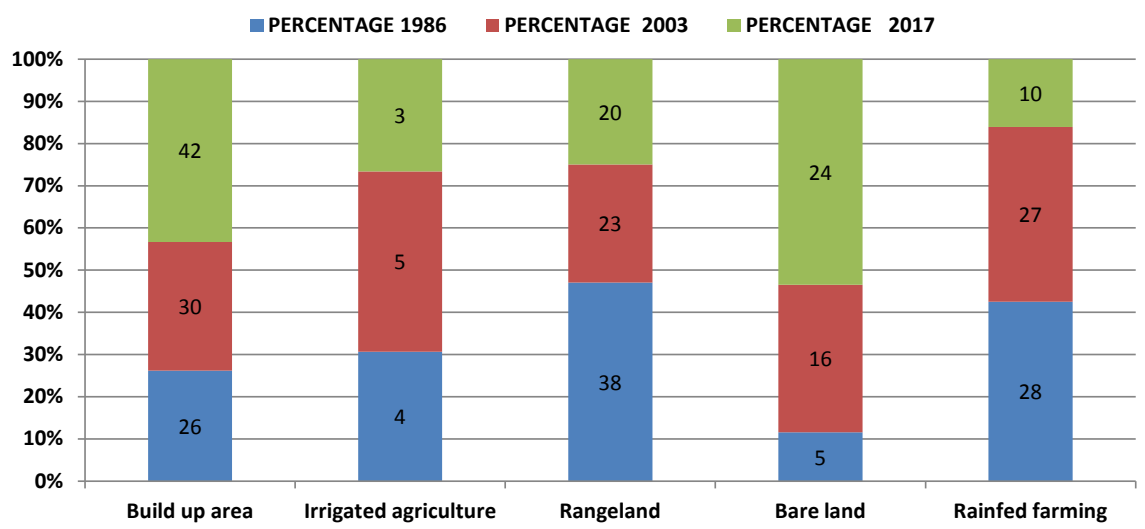

Figure 9. Area percentage of land use/cover classes in 1986, 2003 and 2017.

Table 3. Results of land use/cover change analysis (1986-2017) for Amman area.

\begin{tabular}{cccccccc}
\hline $\begin{array}{c}\text { Land use/cover } \\
\text { class }\end{array}$ & $\begin{array}{c}\text { Area km } \\
1986\end{array}$ & $\begin{array}{c}\% \\
1986\end{array}$ & $\begin{array}{c}\text { Area km }^{2} \\
2003\end{array}$ & $\% 2003$ & $\begin{array}{c}\text { Area km² } \\
2017\end{array}$ & $\% 2017$ & $\begin{array}{c}\text { Change in } \\
\text { percentage } \\
1986-2017\end{array}$ \\
\hline Build up area & 169 & $26 \%$ & 157 & $24 \%$ & 280 & $42 \%$ & $17 \%$ \\
Irrigated agriculture & 24 & $4 \%$ & 33 & $5 \%$ & 20 & $3 \%$ & $-1 \%$ \\
Rangeland & 251 & $38 \%$ & 189 & $29 \%$ & 133 & $20 \%$ & $-18 \%$ \\
Bare land & 34 & $5 \%$ & 103 & $16 \%$ & 158 & $24 \%$ & $19 \%$ \\
Rain fed farming & 182 & $28 \%$ & 177 & $27 \%$ & 69 & $10 \%$ & $-17 \%$ \\
$\quad$ Sum & $659 \mathrm{~km}^{2}$ & $100 \%$ & $659 \mathrm{~km}^{2}$ & $100 \%$ & $659 \mathrm{~km}^{2}$ & $100 \%$ & \\
\hline
\end{tabular}

built with theaters, swimming pools, playing grounds, and a large conference palace. Several gardens were created around the Sports City, and in different places of Amman. Dramatic, progressive changes in LULC, especially in the built up area and the cultivated land, have been taking place in Amman City since the 1950s. Rapid urban growth, and the changes in housing patterns from single-family houses to apartments, caused a remarkable recession and shrinkage in urban open space, including rangeland, wildlife, rainfed and irrigated areas. The fertile irrigated flood plain of "Seil" Amman with an area of 900 hectares (based on aerial photos of 1953, scale 1:25,000) was turned initially into a dumpsite. Then the unwise planning of the Amman Municipality since the 1970s; covered the "Seil" (rather than restoring its catchment) and replaced it by a highway serving the light industrial, commercial, and residential zones extending along the former "Seil". The vast rainfed farming land was gradually invaded by residential apartments/buildings, and other urban utilization. Apart from the relatively high natural growth rate of population (2.4\%) [43], other reasons which have caused a constant upward progression in population growth within the city, are the successive flows of refugees and migrants mainly from neighboring countries: Palestine (1948), West Bank (1967), Iraq (1991 and 2003) and Syria (2011). Most of these persons settled in the capital Amman. 


\subsection{Urban Open Space Quality Confirms the "Two Ammans" Paradigm}

The Amman Metropolitan Area represents a unique city with a "stiking lack of natural, green areas, or agricultural landscape, or even rurban zone". Furthermore, the planners have converted Amman's urban fabric into "a car-oriented space, and unfriendly city for pedestrians" [19]. Thus, Amman is considered a typical example of how to "design against well-being of the city residents and the surrounding nature". During the last 20 years, the political economy, infrastructure and services, education and health, and communication processes, combined with the rapid growth of Amman, have developed consistently under the neo-liberalism to produce "socio-economic disparities between eastern (working class) and western (upper class) parts of the city" [54], or the spaces known as "two Ammans" as described by Ababsa [55]. The structure of social classes in Amman has been evaluated based on annual income, real-state property, and family/tribe origin. Through mapping the spatial distribution of annual income and population density, Ababsa [55] established the spatial pattern which shed useful light on social disparities within the city. She suggests an approximate line between the perceived "two Ammans". Low income classes and highly dense areas dominate eastern Amman, whereas medium and upper class, medium to low dense areas characterize the western part of the city. The existing areal differentiations within the city were decisive in shaping the types and users of available public spaces in the eastern and western parts of Amman. The open spaces in eastern Amman (for example; low quality and small gardens and squares) are simply not user-oriented spaces, and often are bereft of any facilities that motivate popular active use. Whereas the open spaces in western Amman whether public and accessible, or privatized closed spaces designed to be used by certain groups of residents, are replete with, highly Westernized sophisticated facilities (for example, large gardens, swimming pools, with walking tracks surrounded by trees, parks and playgrounds). Urban development in Amman over the last 20 years demonstrates the character and use of the traditional and the produced urban open spaces: 1) the earlier and communal urban public spaces (i.e. Al Husaini Mosque; King Faisal Street, and traditional shopping streets); 2) contemporary open market spaces (i.e. Wakalat Street, Rainbow Street), and closed market spaces (i.e. Mecca Mall and Taj Mall); 3) privatized urban public space/green areas associated with gated communities (i.e. Andalusia gated residential compound), designed based on international standards and modernity; 4) privatized modern market space (i.e. Abdali Towers or what is known as "the new downtown of Amman"). The first two types of urban public spaces are drafted and created by urban planners, whereas the other two types are shaped and produced through a political process as stated by Lefebvre [20], or more specifically, constitute a social and political product [56]. Such open spaces are produced under the neo-liberal economy and Jordan's privatization program, which focused primarily on public services [57]. Neo-liberalism has become the 
dominant political-economic ideology in Jordan over the past two decades, and has significantly impacted the public services, public land, public spaces, squares, markets, paths, and parks. The urban fabric and the social pattern of Amman have been remarkably modified, and new urban spaces were produced [19]. Under the new style of urban open spaces, the social cohesion in the city is expected to further erode to a vanishing point. A comparison between the traditional housing compound of Abu-Nuseir constructed in the mid 1980s (for the low-middle income class) when Jordan was a state of public sectors, and the Andalusia gated community (for the upper income stratum) completed in 2005, when public policy in Jordan was shaped by a neo-liberal government, reveals a genuinely divided city between rich and poor classes. The Abu-Nuseir housing social compound, $20 \mathrm{~km}$ north east of Amman, was completed in 1987. Almost 12,000 inhabitants live in Abu-Nuseir, and it is administered by the Greater Amman Municipality. The housing complex includes: three-story apartment buildings, a number of single-family units, attached, and villa-type houses. The compound is supported by a range of low-quality facilities, such as, schools, retail outlets, health centers, scattered small parks, mosques, and various neighborhood open spaces surrounding the residential buildings. The neighborhood open spaces are rarely used by the residents due to the lack of maintenance and inconvenience of their use. Most of the open spaces are located adjacent to incisions and steep slopes, thus, they are dangerous for use by children and adults. The lack of guard rails, retaining walls, and fences along the edges of many open spaces has rendered their use unsafe. Many neighborhood open spaces are not conducive to socializing [58]. By contrast, the design of public services of the Andalusia gated community (completed in 2005) represents an example of highly Westernized architectural sophistication. The Andalusia gated community is composed of villas, a health club and gymnasium, large swimming pool, tennis and basketball courts with walking tracks surrounded with trees, parks and playgrounds, a children' club, seating areas, cafes and restaurants, and a clinic. The public spaces available in Andalusia are attractive, comprehensive, and diverse. Neither the public spaces nor the community are publicly accessible, open and uncontrolled. By contrast, the community and public spaces of the Abu-Nuseir social housing compound is publicly accessible, open and uncontrolled. The public spaces in Andalusia are privatized within its walls through control and surveillance of the entrances and exist of the compound by means gates and security guards. This in, the long run initiates a sharp social segregation between those who can afford living in a gated compound and pay for the high cost of privatized public space, and those who cannot [19]. It is obvious that the role of planners in producing recent open spaces is simply: the conventional procedural processes familiar in planning practice to create, and control private spaces for particular users. The transformation from "traditional" public spaces of ten created by planners into socially and politically "privatized" public spaces has encouraged social stratification, residential segregation, and geographic in- 
equalities (elite vs. lower social class) and the restriction of social accessibility to particular public spaces. Consequently, the freedom of accessibility to particular open spaces is limited to only within the same urban fabric, thus, enforcing the "two Ammans" paradigm of the city.

\subsection{Changing Housing Patterns and Developed Private Public Spaces}

Intensive urban growth, particularly housing development since the 1980's, was associated with prominent changes in housing style: from single-family houses to apartments in order to meet the needs of a rapidly growing population of the city. This is illustrated by the decline in the number of private houses (i.e. villas, or single-family houses) in the capital Amman, from 9072 units built in 1994 to 7016 and 7367 units constructed in 2004 and 2015 respectively. In contrast, the number of apartments rose sharply, from 265,084 apartments in 1994 to 441,312 and 718,397 in 2004 and 2015 respectively [47] [59] [60]. The increase in the number of apartments and the decline in large independent houses are due to the influence of political disturbances and wars in the region during the last 25 years, coupled with high migration rates, and socio-economic changes; which affected the growth and distribution of the population in the country. Additionally, the social changes as a result of the high level of education in Jordanian society, and the change in the pattern of families; from the traditional extended family, to the modern nuclear family, have caused a rising high demand for housing. The transmission from an architectural style to another across a space in the city (i.e. moving from large single-family houses to apartments), has led to noticeable changes in human behavior. The newly emerged residential areas have no independent home spaces, and public spaces have not been provided, or taken into consideration during the expansion of the city, and the emergence of new housing patterns. Moving from large single-family houses to apartments in a residential building, the residents found themselves unable to practice their activities in the more cramped apartment buildings. Thus, residents began to search for public space to exercise their social and economic activities, whereas the availability of a wide space in a single-family house is often connected to the requirements of daily social activities of residents. Due to the changes mentioned above, an urgent demand for urban public space has emerged, and a huge private sector was developed and excercises a controlling influence over the private open social spaces: (i.e. community gardens and parks, provisions for children, squares; and other urban social spaces: i.e. malls, wedding halls, coffee shops, deewan(s) (a kind of information and consultation place), cultural clubs, sport fields, and readily accessible urban streets; with commercial facilities (such as plazas) inviting people to walk; set and socialize), to encourage group activities and social interactions. The number of specific public spaces and their spatial distribution was mapped and illustrated in Figures 10-13, based on the Greater Amman Municipality surveys. It is as follows: 112 deewans, 144 wedding halls, 58 malls, and 127 parks of different sizes [61]. 


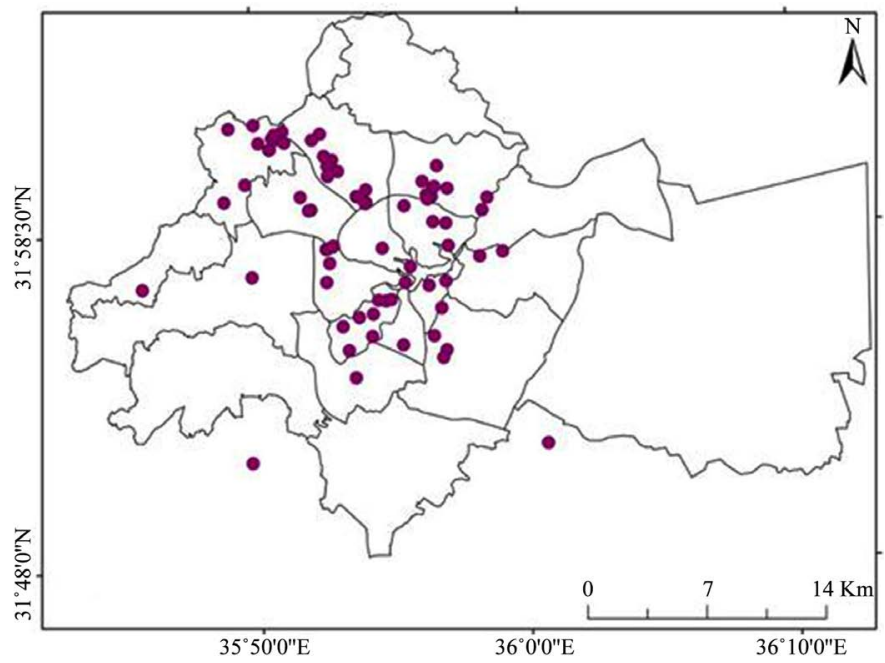

Figure 10. Spatial distribution of deewans.

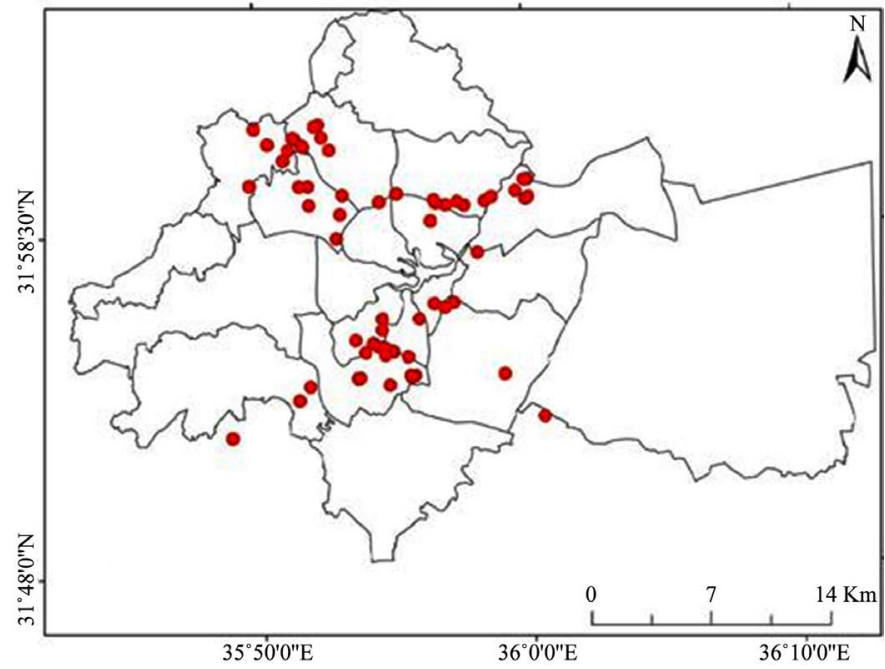

Figure 11. Spatial distribution of wedding halls.

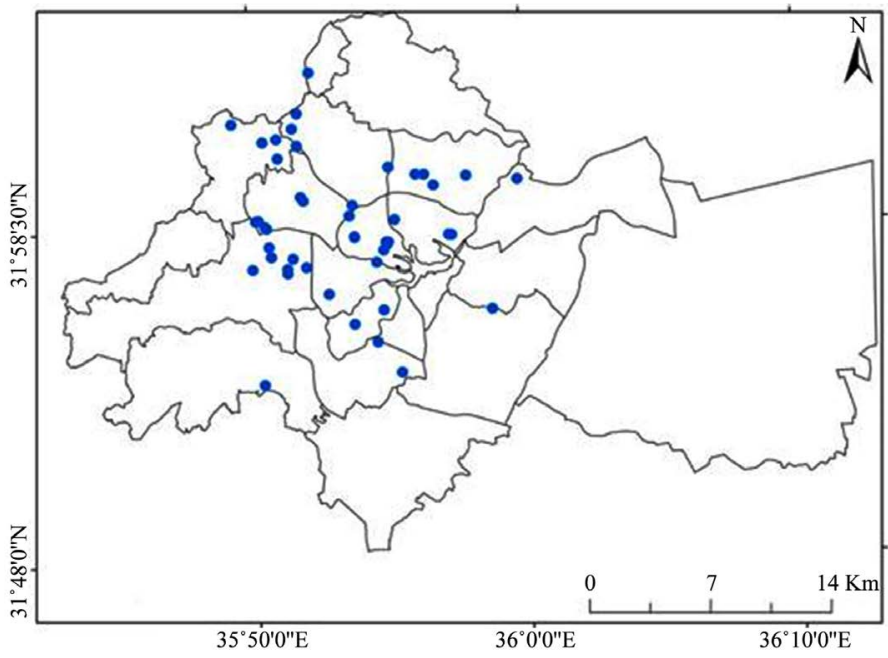

Figure 12. Spatial distribution of malls. 


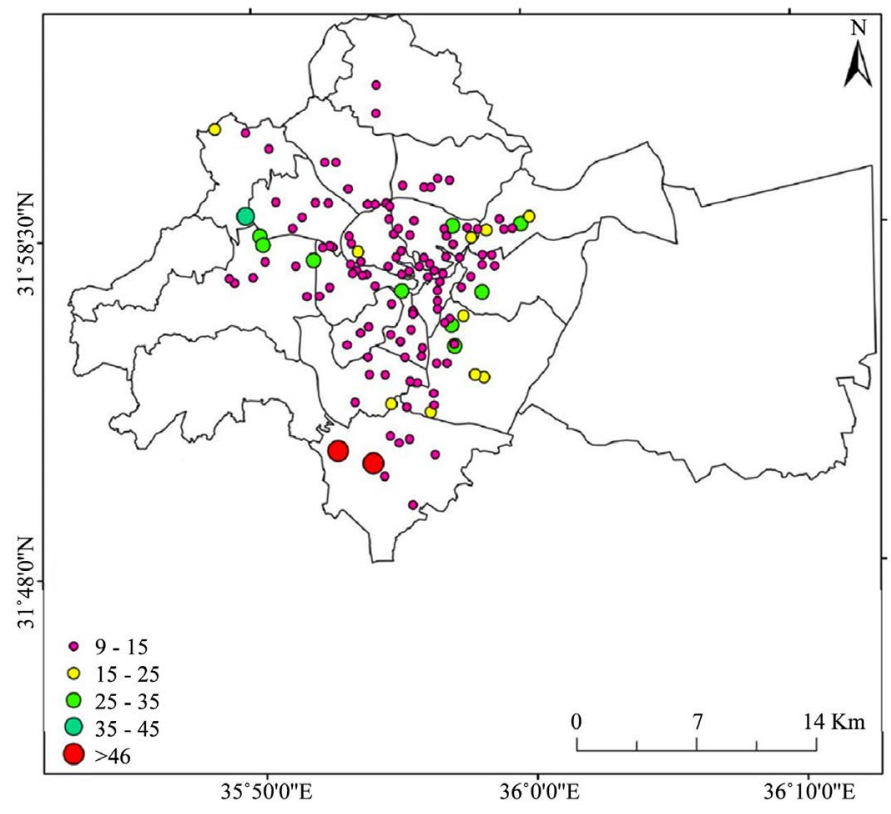

Figure 13. Spatial distribution of gardens by area.

\section{Conclusions}

Rapid urbanization and population growth of the Amman Metropolitan Area since the 1950s, associated with imperfect planning, are the main causes of land resource degradation. Historical analysis of land use/cover dynamics, using successive air photos, satellite images, and supervised classification, indicates that agricultural land, and rangeland were transferred to urban areas. The scarcity of fertile land and rangeland, was coupled with the creation of new urban open public and social spaces, and land resourses have become more vulnerable for further degradation.

Changes in housing patterns (from large single-family houses to residential dense apartments) were associated with social and behavioral changes among inhabitants living in these apartments. Residents here were unable to engage in their social activities in the newly emerged dense residential buildings; thus, they are forced to seek spaces elsewhere. Consequently, an enormous private sector has been developed to provide and control public spaces such as: deewans, wedding halls, malls, and parks of different sizes.

During the last 25 years, the public ownership over the traditional public open spaces of Amman has come to be threatened by recent governmental economic policies. With the transformation from a state of public sector facilities; to a neo-liberal, privately controlled economy, public spaces have been created and shaped based on ongoing political processes rather than scientific planning criteria. Thus, such spaces are deemed a social and political product, and created within the dictates of a neo-liberal economy; which encourages marketization and paivatization practices over providing public facilities, services, resources and spaces, coupled with enhanced public accessibility and equity. Adversely, neoliberalism has created marked socio-economic disparities between eastern 
(the working class) and western (the upper class) sections of the urban socioscape, or the phenomenon a "two Amman" cityscape, as noted elsewhere.

The existing areal differentiations within the city have proved decisive in shaping the types and users of available and newly constructed public spaces in the western and eastern parts of the city. The open public spaces in eastern Amman, for example, are of low quality, and are simply not appropriate for users, and often without facilities that motivate active use. By contrast, the open spaces in western Amman whether public and accessible, or privatized, and closed, i.e. restricted "open" spaces, are designed to be used by certain groups of residents, and furnished with highly Westernized sophisticated facilities. It is recommended that a rational land use policy for Amman must be worked out and prioritized to help in creating new urban democratic, and user-oriented, user-friendly public spaces, equipped with appropriate facilities that motivate active use. The new public space must be designed to provide equal accessibility to all user groups, regardless of age, gender, ethnicity and social class.

\section{Acknowledgements}

The authors wish to thank Mr. Rami Musa of BirZeit University, West Bank/Palestine, for helping in remote sensing analysis.

\section{Conflicts of Interest}

The authors declare no conflicts of interest regarding the publication of this paper.

\section{References}

[1] Neal, Z. (2010) Seeking Common Ground: Three Perspectives on Public Space. Proceedings of the Institution of Civil Engineers. Urban Design and Planning, Vol. 163, San Francisco, CA, 15 January 2010, 59-66.

[2] Lipton, S. (2002) The Value of Public Space. Foreword, York.

[3] Worpole, K. and Knox, K. (2008) The Social Value of Public Spaces. Joseph Rowntree Foundation, New York.

[4] Altman, I. and Zube, E. (1989) Public Places and Spaces. Springer, New York. https://doi.org/10.1007/978-1-4684-5601-1

[5] Korpela, K., De Bloom, J., Sianoja, M., Pasanen, T. and Kinnunen, U. (2017) Nature at Home and Work; Naturally Good? Links between Window Views, Indoor Plants, Outdoor Activities and Employee Well-Being over One Year. Landscape and Urban Planning, 160, 38-47. https://doi.org/10.1016/j.landurbplan.2016.12.005

[6] Cox, D., Hudson, H., Shanahan, D., Fuller, R. and Gatson, K. (2017) The Rarity of Direct Experience of Nature in an Urban Population. Landscape and Urban Planning, 160, 79-84. https://doi.org/10.1016/j.landurbplan.2016.12.006

[7] Rasidi, M., Jamirash, N. and Said, I. (2012) Urban Green Space Design Affects Urban Residents' Social Interaction. Procedia Social and Behavioral Sciences, 68, 464-480. https://doi.org/10.1016/j.sbspro.2012.12.242

[8] Peters, K., Elands, B. and Buijs, A. (2010) Social Interactions in Urban Parks: Simulating Urban Cohesion? Urban Forestry \& Urban Greening, 9, 93-100. 
https://doi.org/10.1016/j.ufug.2009.11.003

[9] Lau, H.M. (20140 Investigating the Small Public Urban Open Spaces at High-Density Cities: A Case Study of Hong Kong. M.Sc. Thesis, Uppsala University, Uppsala.

[10] van Melik, R. (2008) Changing Public Space; the Recent Development of the Dutch City Square. Faculty of Geosciences, Utrecht University, Utrecht.

[11] Carmona, M., Tiesdell, S., Heath, T. and Taner, O. (2010) Public Places and Public Spaces: The Dimensions of Urban Design. Architectural Press, Oxford.

[12] Holland, C., Clark, A., Katz, J. and Peace, S. (2007) Social Interactions in Urban Public Places: Aims and Methods. The Open University, London.

[13] Chen, Y., Liu, T., Xie, X.H. and Marusic, B. (2017) What Attracts People to Visit Community Open Spaces? A Case Study of the Overseas China Town Community in Shenzhen, China. International Journal of Environmental Research and Public Health, 13, 644. https://doi.org/10.3390/ijerph13070644

[14] Schipperijn, T., Bentsen, P., Troelsen, J., Toftager, M. and Stigsdotter, K. (2013) Association between Physical Activity and Characteristics of Urban Green Space. Urban Forestry \& Urban Greening, 12, 109-116. https://doi.org/10.1016/j.ufug.2012.12.002

[15] Barbosa, O., Tratalos, J., Armsworth, P., Davies, R., Fuller, R., Johnson, P. and Gaston, K. (2007) Who Benefits from Access to Green Space? A Case Study from Sheffield, UK. Landscape and Urban Planning, 83, 187-195. https://doi.org/10.1016/j.landurbplan.2007.04.004

[16] Badland, H., Hickey, S., Bull, F. and Giles-Corti, B. (2014) Public Transport Access and Availability in the RESIDE Study: Is It Taking Us Where We Want to Go? Journal of Transport \& Health, 1, 45-49. https://doi.org/10.1016/j.jth.2013.10.001

[17] Giles-Corti, B., Broomhall, M.H., Knuiman, M., Collins, C., Douglas, K., Ng, K., Lange, A. and Donovan, R.J. (2005) Increasing Walking: How Important Is Distance to Attractiveness, and Size of Public Open Space? American Journal of Preventive Medicine, 28, 169-176. https://doi.org/10.1016/j.amepre.2004.10.018

[18] Thompson, C.W. (2002) Urban Open Space in the 21st Century. Landscape and Urban Planning, 60, 59-72. https://doi.org/10.1016/S0169-2046(02)00059-2

[19] Khawaja, H. (2015) Public Spaces under Threat. Scenes from Amman. M.A. Thesis, Polytechnic University, Tours.

[20] Lefebvre, H. (1991) The Production of Space. Blackwell, Oxford.

[21] Friedmann, J. (1988) Life Space and Economic Space. Routledge, New York.

[22] Habermas, J. (1999) The Structural Transformation of the Public Space. The MIT Press, Cambridge.

[23] Ababsa, M. (2011) Citizenship and Urban Issues in Jordan. Presses de l'Institut Français du Proche-Orient, Beirut.

[24] Tawil, M.F., Reicher, C., Jafari, M. and Baeumer, K. (2016) Assessment of Public Space Efficiency in Relation to Spatial Development in Amman: Exploring Indicators to Sustainable Models of Future City Life. Journal of Sustainable Development, 9, 104-117. https://doi.org/10.5539/jsd.v9n3p104

[25] Masri, M. (1963) Report on the Geology of Amman Zarqa Area. Central Water Authority, Amman.

[26] Burdon, D. (1959) Handbook of the Geology of Jordan. Benham and Company Ltd., Colchester. 
[27] Mickbel, S.H. and Zacher, W. (1986) Folded Structure in Northern Jordan. Neues Jahrbuchfür Geologie und Paläontologie Monatshefte, 14, 248-256.

[28] El-Isa, Z. (1983) Seismic Risk in Jordan. Proceedings of the 1st Jordan Geological Conference, Jordan Geological Association, Amman, September 1982, 523-541.

[29] El-Isa, Z., Merghelani, H. and Bazzari, M. (1984) The Gulf of Aqaba Earthquake Swarm of 1983 January-April. Geophysical Journal International, 78, 711-722. https://doi.org/10.1111/j.1365-246X.1984.tb05066.x

[30] Al-Tarazi, E. (2000) The Major Gulf of Aqaba Earthquake, 22 November 1995: Maximum Intensity Distribution. Natural Hazards, 22, 17-27. https://doi.org/10.1023/A:1008109810031

[31] El-Isa, Z. (2013) Seismicity and Seismotectonics of the Gulf of Aqaba Region. Arabian Journal of Geosciences, 6, 3437-3449. https://doi.org/10.1007/s12517-012-0604-8

[32] Greater Amman Municipality (2007) Interim Growth Strategy: Development Manual. Unpublished Report, Amman.

[33] Farhan, Y. and Alnawaiseh, S. (2018) Spatio-Temporal Variation in Rainfall Erosivity over Jordan Using Annual and Seasonal Precipitation. Natural Resources, 9, Article ID: 85571. https://doi.org/10.4236/nr.2018.96016

[34] Khawaldah, H. (2016) A Prediction of Future Land Use/Land Cover in Amman Area Using GIS-Based Markov Model and Remote Sensing. Journal of Geographic Information System, 8, Article ID: 67529. https://doi.org/10.4236/jgis.2016.83035

[35] Al Rawashdeh, S. and Saleh, B. (2006) Satellite Monitoring of Urban Spatial Growth in the Amman Area, Jordan. Journal of Urban Planning and Development, 132, 211-216. https://doi.org/10.1061/(ASCE)0733-9488(2006)132:4(211)

[36] Grove, J.M. (1996) The Relationship Between Pattern and Processes of Social Stratification and Vegetation of an Urban-Rural Watershed. Ph.D. Dissertation, Yale University, New Haven.

[37] Grove, J.M. and Burch, W.R. (1997) A Social Ecological Approach and Application of Urban Ecosystem and Landscape Analysis: A Case Study of Baltimore, Maryland. Urban Ecosystems, 1, 259-275. https://doi.org/10.1023/A:1018591931544

[38] Farhan, Y. and Al-Abdullat, S. (1991) Unplanned Urban Land Use Development Using Remote Sensing Techniques: Greater Amman Case Study. Unpublished Report, Amman.

[39] Chatelard, G. and de Terragon, J.M. (2006) The Empire and the Kingdom. French Cultural Centre, Amman.

[40] Potter, R.B., Darmame, K., Barham, N. and Nortcliff, S. (2007) An Introduction to the Urban Geography of Amman, Jordan. Geographical Paper No. 182, The University of Reading, Reading.

[41] Department of Statistics (DOS) (1952) Characteristics of Buildings and Housing, General Population and Housing Census in Jordan. Amman.

[42] Department of Statistics (DOS) (1961) Characteristics of Buildings and Housing, General Population and Housing Census in Jordan. Amman.

[43] Department of Statistics (DOS) (2012) Jordan in Figures: 2011. Report No. 14, Amman.

[44] Abu-Dayyeh, N. (2006) Persistent Vision: Plans for a Modern Arab Capital, Amman 1955-2002. Planning Perspective, 19, 79-110. https://doi.org/10.1080/0266543042000177922

[45] Department of Statistics (DOS) (1979) Characteristics of Buildings and Housing, 
General Population and Housing Census in Jordan. Amman.

[46] Department of Statistics (DOS) (2002) Jordan in Figures: 2001. Report No. 5, Amman.

[47] Department of Statistics (DOS) (2015) Characteristics of Buildings and Housing, General Population and Housing Census in Jordan. Amman.

[48] Abu Ayyash, A. (1977) Amman City: A Study in Internal Migration and Excessive Urban Growth. The 5th Conference of the Arab Towns Organization, Rabat, 23 March 1977, 154-197.

[49] Department of Statistics (DOS) (2007) Iraqis in Jordan. Their Number and Characteristics. DoS, Fafo, and UNFPA, Amman.

[50] Al-Bakri, J.T., Salahat, M., Suleiman, A., Suifan, M., Hamdan, M.R., Khresat, S. and Kandakji, T. (2013) Impact of Climate and Land Use Changes on Water and Food Security in Jordan: Implications for Transcending "The Tragedy of the Commons". Sustainability, 5, 724-748. https://doi.org/10.3390/su5020724

[51] West, B.G. (1970) Soil Survey in the Baqa'a Valley. Unpublished Report. Ministry of Agriculture, Amman.

[52] Halefom, A., Teshome, A., Sisay, E. and Ahmad, I. (2018) Dynamics of Land Use and Land Cover Change Using Remote Sensing and GIS: A Case Study of Debri Tabor Town, South Gondar, Ethiopia. Journal of Geographic Information System, 10, Article ID: 83580. https://doi.org/10.4236/jgis.2018.102008

[53] Tewfik, M. (1989) Urban land in Jordan: Issues and Policies. Cities, 6, 119-135. https://doi.org/10.1016/0264-2751(89)90065-6

[54] Shteiwi, M. (1996) Class Structure and Inequality in the City of Amman. The City and Its Society. Centre d' Etudes et de Recherches Sur le Moyen-Orient Contemporain, Beirut, 405-424.

[55] Ababsa, M. (2010) Mapping the Social Disparities in Amman. Presses de 1'Institut Français du Proche-Orient, Beirut.

[56] Elden, S. (2004) Understanding Henri Lefebvre: Theory and the Possible. Continuum, New York.

[57] Ababsa, M. and Daher, R. (2013) Cities, Urban Practicies and Nation Building in Jordan. Presses de 1'Institut Français du Proche-Orient, Beirut.

[58] Abu-Ghazzeh, T.M. (1996) Reclaiming Public Space: The Ecology of Neighborhood Open Spaces in the Town of Abu-Nuseir, Jordan. Landscape and Urban Planning, 36, 197-216. https://doi.org/10.1016/S0169-2046(96)00343-X

[59] Department of Statistics (DOS) (1994) Characteristics of Buildings and Housing, General Population and Housing Census in Jordan. Amman.

[60] Department of Statistics (DOS) (2004) Characteristics of Buildings and Housing, General Population and Housing Census in Jordan. Amman.

[61] Greater Amman Municipality (2008) The Amman Plan: Metropolitan Growth. Amman. 